\title{
Evidence Based Library and Information Practice
}

\section{Evidence Summary}

\section{Reference Services in Australian Academic Libraries are Becoming More Multifaceted}

\section{A Review of:}

Burke, L. "Models of Reference Services in Australian Academic Libraries." Journal of Librarianship and Information Science 40.4 (2008): 269-86.

\section{Reviewed by:}

Lotta Haglund

Head of Information and Public Relations, Karolinska Institutet, University Library

Stockholm, Sweden

Email: lotta.haglund@kib.ki.se

David Herron

Scholarly Developer, Karolinska Institutet, University Library

Stockholm, Sweden

Email: $\underline{\text { david.herron@ki.se }}$

Received: 02 March 2009

Accepted: 05 June 2009

(C) 2009 Haglund and Herron. This is an Open Access article distributed under the terms of the Creative Commons Attribution License (http://creativecommons.org/licenses/by/2.0), which permits unrestricted use, distribution, and reproduction in any medium, provided the original work is properly cited.

\begin{abstract}
Objective - To investigate the current organizational models for reference work in Australian academic libraries, and how these reference services are staffed.

Design - Mixed methods.

Setting - Academic universities in Australia.

Subjects - Forty Council of Australian University Librarians (CAUL) member libraries.
\end{abstract}

Methods - A literature study was undertaken to (1) find a definition of reference services and (2) explore the development of reference service models over time. Statistics from the CAUL member libraries were studied for trends in student population and number of academic and library staff. A web-based survey, with questions based on the findings in the literature study, was then distributed to the 40 Australian university libraries in 2006.

Respondents were asked when the library commenced different reference services in five areas: formats in which the library received and responded to reference queries, information literacy, subject specialization, liaison activities, and collection development. Respondents also answered questions about the organization of the reference department, 
including: whether they had a separate or integrated model; the size of the reference collections; if they had a librarian dedicated to supporting students studying in remote or distant mode; if the interlibrary loans department was part of the suite of reference services; and if they had a mission or statement of purpose for their reference services department.

Main Results - Based on the literature study, the working definition of reference services (1) for the project was "all activities which assist in providing relevant and appropriate information services to patrons" (270), including:

- All interactions with patrons to assist them in their searches for information in all media types.

- All training by librarians of patrons to be able to access information for themselves.

- Activities to help the library stay informed of relevant developments, such as establishing and maintaining relationships with patrons.

The literature study also revealed (2) a shift from the traditional reference service model, focused on the reference desk and the services delivered from that location, to new models involving "consolidation of reference service points, establishment of tiered reference, reference by appointment, reorganization of reference departments, and limiting services to primary users" (271).

The core aspects of reference services have changed little over time, including face-to-face reference work, print collection development, bibliographic instruction, and attending meetings. In some aspects, however, there has been a shift in emphasis, e.g., in bibliographic instruction from the teaching of tools to the teaching of information literacy. In addition, reference work has come to include "going out to users," or academic liaison work, as well as research consultation as a general way to assist undergraduate student in getting started on assignments and projects.
The Web-based survey $(\mathrm{n}=40$, response rate $87.5 \%$ ) showed that $32.4 \%$ of libraries have an integrated inquiry point which incorporates information queries and other queries that are not necessarily related to traditional library reference services (272, Table 1 ). This survey result supports the findings of the literature study in showing a trend of library services moving away from the traditional reference desk.

A majority of the responding libraries still retained a separate reference department, but a significant number of libraries have developed departments incorporating reference services with other library services. Those that retained the separate department varied in how they described services to patrons, the most common name being Information Services, a more user-friendly and descriptive name.

In staffing the reference service, the respondents were asked to indicate the classification level of their staff using the Higher Education Worker (HEW) scale (an Australian salary scale, based on competencies, minimum 1 / maximum 10 ). Staff spans a variety of levels (4-10), the most common level being HEW6, a level where all libraries had staff. This indicates that a large part of reference staff in Australian academic libraries are highly qualified.

The shift in higher education, resulting in greater numbers of students and fewer staff (including librarians), has in many libraries resulted in a more flexible organization of reference services, and the utilization of staff from other sections of the library for manning the reference service point. There is also evidence of how the changing student population leads to changing demands for library facilities and services, e.g. a decrease in the traditional complex reference questions, as well as in over the counter loan transactions, and an increase in more general queries.

Conclusion - Reference services in Australian academic libraries are becoming more flexible and integrated (although the definition for integrated is still unclear), in part as the result 
of client demand, and in part due to decreased funding. The author sees an emerging role for reference librarians in helping patrons to navigate the increasingly complex information environment, and to assist in developing the skills to critically evaluate the information they access for authoritativeness and appropriateness.

\section{Commentary}

The article provides an interesting historical overview of the development of the definition of reference services, as well as a summary of reference service models and the different aspects of reference services. The author mentions Samuel Green as the father of reference services, being the first librarian to advocate personal assistance to readers. Green encouraged librarians to "mingle with readers" (Green 80), a suggestion that has inspired librarians to start working as roving (or roaming) reference librarians, an alternative or complement to the traditional reference desk, that has been discussed and used during the last 15 to 20 years (Gourtois and Liriano; Kramer). One wonders why this aspect was not revealed in the overview of reference service models, nor did it appear in the results of the web-based survey. For the international audience it would also have been useful had the article placed the Australian findings in a broader context by comparing results from this study with similar overseas studies in the discussion.

As mentioned above, the article is not entirely clear about the meaning of 'integrated' when, for example, stating in the Conclusion, "... to a more flexible, integrated model ..." (275). It would have increased the understanding of the article had the author defined the word integrated in this context.

The article lacks some information concerning the Web-based survey, most importantly the survey questions, without which the validity and reliability of the study is harder to determine. The reviewer also notes, somewhat surprisingly, that the respondents have not been de-identified. If the individual libraries did agree to have their comments identified, it would be preferable for this to be stated in the article.

The appendices section comprises a large part of the article, and, with small exceptions, present the results in a clear and easily understood way. The exceptions include Appendix 1 (library statistics) and Appendix 2 (student statistics) which both take a fair amount of time to draw conclusions from without the summary in the text. It is hard to see how interesting this is for the reader outside Australia. The usefulness of the tables of numbers in the appendices would have been greater had the author chosen to use proportions instead of absolute numbers, which tells us very little.

For the non-Australian reader the Higher Education Worker Levels (HEW) would benefit from some additional explanation since corresponding systems do not exist in all countries.

The results presented in Appendix 3, table A4 - A9 are not presented in the text, but only referred to as "a summary of survey responses is included as Appendix 3" (272). In the text, the author presents the findings concerning service points and staffing, but leaves to the reader to draw conclusions about the more specific trends in reference services from the tables. Since the tables in this appendix provide information relevant to the objectives of the article, it would have been interesting if the author had chosen to expand on these findings in the text.

The article provides an interesting contribution to the understanding of the development of reference services in Australian academic libraries, which should be of interest to reference service managers everywhere. 


\section{Works Cited}

Courtois, M., and Maira Liriano. “Tips for Roving Reference." College \& Research Libraries News 61.4 (2000): 289-91.
Green, S. "Personal Relations Between Librarians and Readers." American Library Journal 1.1 (1876): 74-81.

Kramer, E.H. "Why Roving Reference: A Case Study in a Small Academic Library." Reference Services Review 24.3 (1996): 67- 81. 